\title{
PENGARUH PROFESIONALISME, PENGALAMAN, DAN \\ PENGETAHUAN AUDITOR TERHADAP KUALITAS AUDIT (STUDI EMPIRIS PADA KANTOR AKUNTAN PUBLIK DI MAKASSAR)
}

\author{
THE EFFECT OF PROFESSIONALISM, EXPERIENCE, AND KNOWLEDGE \\ OF AUDITORS TOWARD AUDIT QUALITY \\ (EMPIRICAL STUDY ON PUBLIC ACCOUNTANT OFFICE IN MAKASSAR)
}

\author{
Aan Digita Malik \\ Universitas Borneo Tarakan \\ aan_digita@yahoo.com
}

\begin{abstract}
Abstrak : Penelitian ini bertujuan untuk menguji pengaruh profesionalisme, pengalaman, dan pengetahuan auditor terhadap kualitas audit dalam hal ini ketepatan dalam pemberian opini auditor pada KAP di Makassar. Data dalam penelitian ini diperoleh dari masing - masing KAP di Kota Makassar yang bersedia menjadi responden. Penulis menggunakan pendekatan kuantitatif untuk menjawab permasalahan tersebut menggunakan data primer dalam bentuk kuesioner.. Sebelum melakukan analisis data, peneliti melakukan uji validitas dan reliabilitas terhadap 34 responden untuk menunjukkan sejauh mana kuesioner tersebut dapat dipercaya dan diandalkan. Teknik analisis data yang digunakan dalam penelitian ini adalah teknik analisis regresi berganda. Hasil penelitian menunjukkan bahwa: secara parsial, variabel profesionalisme, pengalaman, dan pengetahuan auditor berpengaruh secara positif dan signifikan terhadap kualitas audit.
\end{abstract}

Kata kunci: Profesionalisme, Pengalaman, Pengetahuan Auditor Dan Kualitas Audit

Abstract : This study purpose to examine the effect of auditor's professionalism, experience, and knowledge on audit quality in this case the accuracy in giving auditor's opinion on KAP in Makassar. The data in this study were obtained from each KAP in Makassar City who were willing to become respondents. The author uses a quantitative approach to answer these problems using primary data in the form of a questionnaire. Before conducting data analysis, researchers conducted a validity and reliability test of 34 respondents to show the extent to which the questionnaire was reliable and reliable. Data analysis technique used in this study is multiple regression analysis techniques. The results showed that: partially, the variable professionalism, experience, and auditor's knowledge had a positive and significant effect on audit quality.

key words : professionalism, experience, knowledge, and Audit Quality 


\section{LATAR BELAKANG}

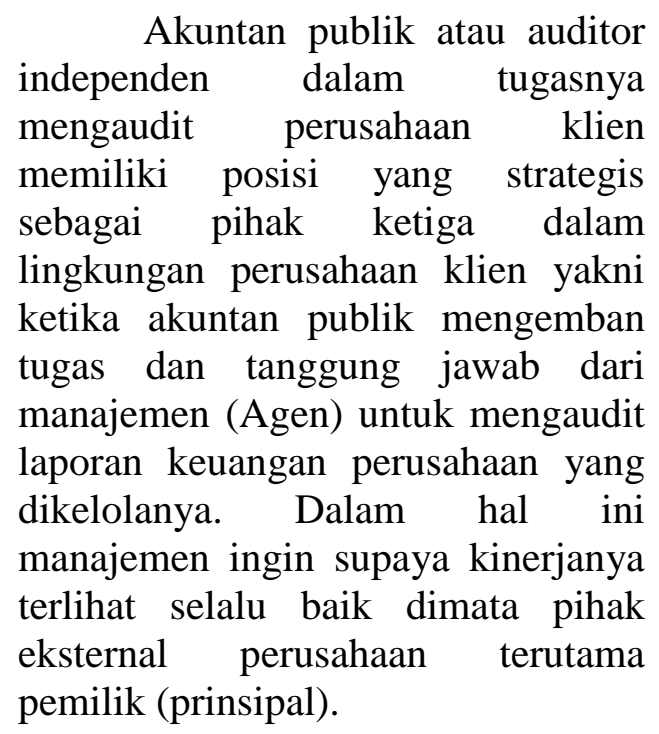

Akan tetapi disisi lain, pemilik (prinsipal) menginginkan supaya auditor melaporkan dengan sejujurnya keadaan yang ada pada perusahaan yang telah dibiayainya. Dari uraian di atas terlihat adanya suatu kepentingan yang berbeda antara manajemen dan pemakai laporan keuangan.Kepercayaan yang besar dari pemakai laporan keuangan auditan dan jasa lainnya yang diberikan oleh akuntan publik inilah yang akhirnya mengharuskan akuntan publik memperhatikan kualitas audit yang dihasilkannya.

Kualitas audit ini penting karena dengan kualitas audit yang tinggi maka akan dihasilkan laporan keuangan yang dapat dipercaya sebagai dasar pengambilan keputusan. Selain itu adanya kekhawatiran akan merebaknya sekandal keuangan, dapat mengikis kepercayaan publik terhadap laporan keuangan auditan dan profesi akuntan publik.De angelo (1981) dalam Cahya Baharuddin (2015:2), Kualitas audit sebagai probabilitas bahwa auditor akan menemukan dan melaporkan pelanggaran pada sistem akuntansi klien. Kemungkinan dimana auditor akan menemukan salah saji tergantung pada kualitas pemahaman auditor yaitu pengalaman dan pengetahuan sementara tindakan melaporkan salah saji tergantung pada sikap profesionalisme auditor.

Pengalaman auditor dalam melakukan pemeriksaan laporan keuangan menjadi salah satu faktor yang mempengaruhi kualitas audit. Pengetahuan auditor akan semakin berkembang seirirng bertambahnya pengalaman melakukan tugas audit. Paragraf ketiga SA seksi 210 menyebutkan: "Dalam melaksanakan audit untuk sampai pada suatu pernyataan pendapat, auditor harus senantiasa bertindak sebagai seorang ahli dalam bidang akuntansi dan bidang auditing.

\section{PERUMUSAN MASALAH}

Berdasarkan latar belakang di atas, maka rumusan masalah dalam penelitian ini adalah sebagai berikut:

1. Apakah profesionalisme berpengaruh terhadap kualitas audit?

2. Apakahpengalaman berpengaruh terhadap kualitas audit?

3. Apakah pengetahuan auditor berpengaruh terhadap kualitas audit?

\section{TINJAUAN PUSTAKA}

$\underline{\text { Profesionalisme Auditor }}$

$\begin{array}{lcc}\quad \text { Menurut } & \text { Kamus Besar } & \text { Bahasa } \\ \text { Indonesia } & \text { (2005: } & 897), \\ \text { Profesionalisme } & \text { adalah } & \text { mutu, }\end{array}$


kualitas dan tindak tanduk yang merupakan ciri suatu profesi atau orang yang profesional. Dalam pelaksanaan pemeriksaan dan penyusunan laporan audit, pemeriksa wajib menggunakan kemahiran profesionalnya dengan cermat dan seksama yang tercantum dalam standar umum yang pertama dalam Standar Profesional Akuntan Publik (SPAP) yang ditetapkan oleh Ikatan Akuntan Indonesia (Al Haryono Jusup, 2001: 53). Adapun pengertian Profesionalisme menurut Kalbers dan Fogarty (1995: 72), yaitu suatu atribut individual yang penting tanpa melihat suatu pekerjaan merupakan suatu profesi atau tidak. Sedangkan menurut Anita Kusuma Dewi (2010: 22), "Profesionalisme adalah sikap atau semangat mempertahankan suatu profesi dan memelihara citra publik terhadapnya serta menekuni ilmu dan substansi pekerjaan dalam bidang tersebut".

Konsep profesionalisme modern dalam melakukan suatu pekerjaan telah dikemukakan oleh Hall, et, al (1968) dalam Ramdanialsyah (2010), bahwa menurutnya profesionalisme berkaitan dengan dua aspek penting yaitu aspek struktural dan aspek sikap. Aspek struktural yang karakteristiknya merupakan bagian dri pembentukan sekolah penelitian, pembentukan asosiasi profesional dan pembentukan kode etik. Sedangkan aspek sikap berkaitan dengan pembentukan jiwa profesional.

\section{$\underline{\text { Pengalaman Auditor }}$}

Pengalaman adalah proses pembelajaran diri yang diperoleh dari pendiikan formal maupun non formal. Pengalaman kerja merupakan penguasaan dan pemahaman seseorang atas pekerjaannya. Pengalaman dan pengetahuan merupakan faktor penting untuk meningkatkan keahlian (Purnamasari, 2005). Pengalaman seorang auditor dapat diukur dari lamanya seorang auditor bekerja, banyaknya kasus yang dikerjakan, dan seringnya pelatihan yang diikuti.
Anning
(2006)
dalam

Ramdanialsyah (2010) memberikan kesimpulan bahwa seorang yang memilii pengalaman kerja yang tinggi akan memiliki keunggulan dalam bebrapa hal diantaranya; 1). Mendeteksi kesalahan, 2). Memahami kesalahan, dan 3). Mencari penyebab munculnya kesalahan. Keunggulan tersebut bermanfaat bagi pengembangan keahlian.

\section{$\underline{\text { Pengetahuan Auditor }}$}

Pengetahan auditor adalah hal yang sangat penting dalam meningkatkan kualitas audit. Pengetahuan auditor yang tinggi dan luas juga dapat mempengaruhi kualitas audit. Pengetahuan auditor biasanya dapat diukur dengan tingkat pengalaman kerja sebagai seorang auditor. Semakin lama auditor memperoleh pengalaman kerja maka akan dapat dikatakan semakin tinggi juga tingkat pengetahuan yang mereka miliki atau peroleh (Salsabila dan Prayudiawan,2011:158). Hal tersebut membuktikan bahwa suatu pengetahuan dapat mempengaruhi hubungan akuntabilitas dengan kualitas hasil kerja auditor jika kompleksitas pekerjaan yang akan 
dihadapi sedang/menengah. Adapun Standar Profesional Akuntan Publik (SPAP) 2001 tentang standar umum, menjelaskan bahwa dalam melakukan audit, auditor harus memiliki keahlian dan struktur pengetahuan yang cukup.

$\underline{\text { Kualitas Audit }}$

Akuntan publik atau auditor independen dalam menjalankan tugasnya harus memegang prinsipprinsip profesi. Menurut Simamora (2002:47) ada 8 prinsip yang harus dipatuhi akuntan publik yaitu : 1) Tanggung jawab profesi. Setiap anggota harus menggunakan pertimbangan moral dan profesional dalam semua kegiatan yang dilakukannya. 2) Kepentingan publik. Setiap anggota berkewajiban untuk senantiasa bertindak dalamkerangka pelayanan kepada publik, menghormati kepercayaan publik dan menunjukkan komitmen atas profesionalisme. 3) Integritas. Setiap anggota harus memenuhi tanggung jawab profesionalnyadengan intregitas setinggi mungkin. 4) Objektivitas.Setiap anggota harus menjaga objektivitasnya dan bebas daribenturan kepentingan dalam pemenuhan kewajiban profesionalnya. 5) Kompetensi dan kehati-hatian profesional. Setiap anggota harus melaksanakan jasa profesionalnya denganhati-hati, kompetensi dan ketekunan serta mempunyai kewajiban untuk mempertahankan pengetahuan dan keterampilan profesional. 6) Kerahasiaan. Setiap anggota harus menghormati kerahasiaan informasi yang diperoleh selama melakukan jasa profesional dan tidak boleh memakai atau mengungkapkan informasi tersebut tanpa persetujuan. 7) Perilaku Profesional. Setiap anggota harus berperilaku yang konsisten dengan reputasi profesi yang baik dan menjauhi tindakan yang dapat mendiskreditkan profesi. 8) Standar TeknisSetiap anggota harus melaksanakan jasa profesionalnya dengan standar teknis dan standar profesional yang relevan.

Kualitas audit merupakan hal yang penting karena kualitas audit yg tinggi akan menghasilkan laporan keuangan yang dapat dipercaya sebagai dasar pengambilan keputusan (Cahya Baharuddin, 2015:14).

$\underline{\text { Hipotesis }}$

H1: Profesionalisme berpengaruh Positif dan Signifikan TerhadapKualitas Audit.

$\mathrm{H} 2$ : Pengalaman berpengaruh Positif dan Signifikan Terhadap Kualitas Audit.

H3: Pengetahuan berpengaruh Positif dan Signifikan Terhadap Kualitas Audit.

\section{METODOLOGI PENELITIAN}

$\underline{\text { Desain Penelitian }}$

Metode penelitian yang
digunakan untuk menentukan
pengaruh variabel independen (X)
terhadap variabel dependen (Y)
adalah penelian kuesioner.
Pengiriman kuesioner dilakukan
secara langsung, yaitu dengan

Metode penelitian yang digunakan untuk menentukan pengaruh variabel independen $(\mathrm{X})$ terhadap variabel dependen (Y) adalah penelian kuesioner. secara langsung, yaitu dengan 
mengirimkan langsung kepada kantor yang bersangkutan.

\section{$\underline{\text { Metode Analisis Data }}$}

Metode statistik yang digunakan untuk menguji hipotesis adalah dengan menggunakan regresi berganda dengan bantuan perangkat lunak SPSS for windows, setelah semua data - data dalam penelitian ini terkumpul, maka selanjutnya dilakukan analisis data yang terdiri dari:

\section{$\underline{\text { Uji Statistik Deskriptif }}$}

Statistik deskriptif
memberikan gambaran atau
deskripsi suatu data yang dilihat dari
nilai rata-rata (mean), standar
deviasi, varian, maksimum,
minimum, sum, range, kurtosis dan
skewness (Ghozali, 2009: 19).

\section{$\underline{\text { Uji Kualitas Data }}$}

Pengujian kualitas data yang dilakukan dengan cara penyebaran kuesioner, maka kesediaan dan ketelitian dari para responden untuk menjawab setiap pertanyaan merupakan suatu hal yang sangat penting dalam penelitian ini. Keabsahan suatu jawaban sangat ditentukan oleh alat ukur yang ditentukan. Untuk itu, dalam melakukan uji kualitas data atas data primer ini peneliti melakukan uji validitas dan uji reabilitas

1. Uji Validitas

Uji validitas digunakan untuk mengukur sah atau valid tidaknya suatu kuesioner.
2. Uji Reliabilitas

Reliabilitas menunjuk pada suatu pengertian bahwa sesuatu instrumen cukup dapat dipercaya untuk diinginkan sebagai alat pengumpul data karena instrumen tersebut sudah baikUji Asumsi Klasik

3. Uji Normalitas

Ghozali (2009:147) uji normalitas bertujuan apakah dalam model regresi variabel dependen (terikat) dan variabel independen (bebas) mempunyai kontribusi atau tidak. Penelitian yang menggunakan metode yang lebih handal untuk menguji data mempunyai distribusi normal atau tidak yaitu dengan melihat Normal Probability Plot. Model Regresi yang baik adalah data distribusi normal atau mendekati normal, untuk mendeteksi normalitas dapat dilakukan dengan melihat penyebaran data (titik) pada sumbu diagonal grafik. (Ghozali, 2009).

4. Uji Multikolinieritas

Uji multikolinieritas ini diperlukan untuk mengetahui ada tidaknya variabel independen yang memiliki kemiripan dengan variabel independen lain dalam satu model.

5. Uji Heteroskedastisitas

Heteroskedastisitas adalah varian residual yang tidak konstan pada regresi sehingga akurasi hasil prediksi menjadi meragukan.

\section{$\underline{\text { Uji Hipotesis }}$}

Uji Persamaan Regresi Linier Berganda

Pengujian hipotesis ini dilakukan dengan menggunakan metode analisis regresi linier berganda yang bertujuan untuk menguji hubungan 
pengaruh antara satu variabel terhadap variabel lain.

\section{$\underline{\text { Uji Determinasi }}$}

Koefisien determinasi bertujuan untuk mengukur seberapa jauh kekuatan model dapat menjelaskan variasi variabel dependen. Dalam pengujian hipotesis pertama koefisien determinasi dilihat dari besarnya nilai Adjusted $\mathrm{R}$ Square (Adjusted $R^{2}$ ) untuk mengetahui seberapa jauh variabel bebas yaitu profesionalisme, penglaman dan pengetahuan auditor terhadap Kualitas Audit. Nilai $\mathrm{R}^{2}$ mempunyai interval antara 0 sampai $1\left(0 \leq \mathrm{R}^{2} \leq\right.$ 1). Jika nilai $\mathrm{R}^{2}$ bernilai besar (mendekati 1) berarti variabel bebas dapat memberikan hampir semua informasi yang dibutuhkan untuk memprediksi variabel dependen. Sedangkan jika Adjusted $R^{2}$ bernilai kecil berarti kemampuan variabel bebas dalam menjelaskan variabel dependen sangat terbatas (Ghozali, 2009:87).

\section{$\underline{\text { Uji Statistik F }}$}

Pengujian ini bertujuan untuk membuktikan apakah variabelvariabel independen (X) secara simultan (bersama-sama) mempunyai pengaruh terhadap variabel dependen (Y). (Imam Ghozali, 2009:88). independen secara individu dalam menerangkan variabel dependen (Imam Ghozali, 2009:88).

\section{HASIL DAN PEMBAHASAN}

$\underline{\text { Hasil }}$

Penelitian ini dilakukan terhadap auditor yang bekerja pada Kantor Akuntan Publik di Makassar. Dari 8 kantor akuntan publik yang ada di Makassar, yang bersedia untuk turut serta dalam penelitian hanya 6 Kantor Akuntan Publik.

\begin{tabular}{|c|l|c|c|c|}
\hline No & Nama KAP & $\begin{array}{c}\text { Juml } \\
\text { ah } \\
\text { Aud } \\
\text { itor }\end{array}$ & $\begin{array}{c}\text { Kuesi } \\
\text { oner } \\
\text { yang } \\
\text { diseba } \\
\text { r }\end{array}$ & $\begin{array}{c}\text { Kuesi } \\
\text { oner } \\
\text { yang } \\
\text { diisi }\end{array}$ \\
\hline 1 & $\begin{array}{l}\text { Drs. Thomas, } \\
\text { Blasius, } \\
\text { Widartoyo \& } \\
\text { Rekan }\end{array}$ & 7 & 7 & 7 \\
\hline 2 & $\begin{array}{l}\text { Drs. Rusman } \\
\text { Thoeng, } \\
\text { M.Com, BAP }\end{array}$ & 5 & 5 & 5 \\
\hline 3 & $\begin{array}{l}\text { Drs. Harly } \\
\text { Weku }\end{array}$ & 5 & 5 & 5 \\
\hline 4 & $\begin{array}{l}\text { Drs. Usman \& } \\
\text { Rekan }\end{array}$ & 6 & 6 & 6 \\
\hline 5 & $\begin{array}{l}\text { Yakub Ratan, } \\
\text { CPA }\end{array}$ & 6 & 6 & 6 \\
\hline 6 & $\begin{array}{l}\text { Jojo Sunarjo } \\
\text { \& Rekan }\end{array}$ & 5 & 5 & 5 \\
\hline \multicolumn{2}{|l|}{ Jumlah } & 34 & 34 & 34 \\
\hline
\end{tabular}

\section{$\underline{\text { Uji Statistik t }}$}

Uji statistik $t$ pada dasarnya menunjukkan seberapa jauh pengaruh satu variabel individu 
Hasil Uji Instrumen Penelitian Hasil Uji Statistik Deskriptif

\begin{tabular}{|l|r|r|r|r|r|}
\hline & $\mathrm{N}$ & $\begin{array}{c}\text { Mi } \\
\text { nim } \\
\text { um }\end{array}$ & $\begin{array}{c}\text { Maxi } \\
\text { mum }\end{array}$ & $\begin{array}{c}\text { Me } \\
\text { an }\end{array}$ & $\begin{array}{c}\text { Std. } \\
\text { Devi } \\
\text { ation }\end{array}$ \\
\hline $\begin{array}{l}\text { Profesio } \\
\text { nalisme }\end{array}$ & 34 & 36. & 45.00 & 41. & 3.074 \\
& 00 & & 058 & 24 \\
8 & \\
Pengala & 34 & 20. & 25.00 & 23. & 1.794 \\
man & & 00 & & 411 & 23 \\
& & & 8 & \\
Pengeta & 34 & 24. & 30.00 & 27. & 2.0373 \\
huan & & 00 & & 029 & 1 \\
Kualitas & 34 & 40. & 50.00 & 46. & 3.482 \\
Audit & & 00 & & 147 & 70 \\
Valid N & 34 & & & 1 & \\
\hline
\end{tabular}

Tabel di atas menjelaskan hasil statistik deskriptif tentang variabel-variabel dalam penelitian ini, antara lain

1. Profesionalisme $\left(\mathrm{X}_{1}\right)$

Berdasarkan tabel 6 diatas $\mathrm{X}_{1}$ memiliki nilai minimum 36 , nilai maksimum 45, dan mean 41,0588 dengan 9 item pertanyaan maka $(41,0588: 9=4,5620$ sehingga 4,5620 berada di skala nilai yang menunjukkan pilihan jawaban sangat setuju. Nilai standar deviasi menunjukkan adanya penyimpangan sebesar 3,0742 dari nilai rata-rata jawaban responden.

\section{Pengalaman $\left(\mathrm{X}_{2}\right)$}

Berdasarkan tabel 6 diatas $\mathrm{X}_{2}$ memiliki nilai minimum 20 , nilai maksimum 25, dan mean 23,4118 dengan 5 item pertanyaan maka $(23,4118: 5=4,6823)$ sehingga 4,6823 berada di skala nilai yang menunjukkan pilihan jawaban sangatsetuju. Nilai standar deviasi menunjukkan adanya penyimpangan sebesar 1,7942dari nilai rata-rata jawaban responden.

3. Pengetahuan $\left(\mathrm{X}_{3}\right)$

Berdasarkan tabel 8diatas $\mathrm{X}_{3}$ memiliki nilai minimum 24 , nilai maksimum 30, dan mean 27,0294 dengan 6 item pertanyaan maka $(27,0294: 6=4,5049)$ sehingga 4,5049 berada di skala nilai yang menunjukkan pilihan jawaban sangat setuju. Nilai standar deviasi menunjukkan adanya penyimpangan sebesar 2,0373dari nilai rata-rata jawaban responden.

Kualitas Audit (Y)

Berdasarkan tabel 8diatas $\mathrm{Y}$ memiliki nilai minimum 40 , nilai maksimum 50, dan mean 46,1471dengan 10 item pertanyaan maka $(46,1471: 10=4,6147)$ sehingga 4,6147 berada di skala nilai yang menunjukkan pilihan sangat setuju. Nilai standar deviasi menunjukkan adanya penyimpangan sebesar 3,4827dari nilai rata-rata jawaban responden 
$\underline{\text { Model Persamaan Regresi }}$

\section{Coefficients $^{\mathrm{a}}$}

\begin{tabular}{|c|r|r|r|}
\hline \multirow{2}{*}{ del Mo } & \multicolumn{2}{|c|}{$\begin{array}{c}\text { Unstandardize } \\
\text { d Coefficients }\end{array}$} & $\begin{array}{c}\text { Standardi } \\
\text { zed } \\
\text { Coefficie } \\
\text { nts }\end{array}$ \\
\cline { 2 - 4 } & B & $\begin{array}{c}\text { Std. } \\
\text { Error }\end{array}$ & Beta \\
\hline $\begin{array}{l}\text { (Consta } \\
\text { nt) } \\
\text { Profesio } \\
\text { nalisme } \\
1\end{array}$ & .415 & 8.428 & .319 \\
$\begin{array}{l}\text { Pengala } \\
\text { man } \\
\text { Pengeta } \\
\text { huan }\end{array}$ & .721 & .289 & .371 \\
\hline
\end{tabular}

Berdasarkan tabel diatas, maka persamaan regresi yang terbentuk pada uji regresi ini adalah:

$Y=0,415+0,319 X_{1}+0,721 X_{2}+$ $\mathbf{0 , 5 8 3} \mathrm{X}_{3}+\mathrm{e}$

Model tersebut dapat diinterpretasikan sebagai berikut:

1. Nilai konstanta adalah 0,415 ,ini menunjukkan bahwa jika variabel independen (profesionalisme, pengalaman, dan pengetahuan auditor) bernilai nol (0), maka nilai variabel dependen (kualitas audit) sebesar 0,412satuan.

2. Koefisien regresi profesionalisme $\left(b_{1}\right)$ adalah 0,319 dan bertanda positif. Hal ini berarti, nilai variabel $\mathrm{Y}$ akan mengalami kenaikan sebesar 0,319 jika nilai variabel $\mathrm{X}_{1}$ mengalami kenaikansatu satuan dan variabel independen lainnya bernilai tetap. Koefisien bertanda positif menunjukkan adanya hubungan yangsearah antara variabel profesionalisme $\left(\mathrm{X}_{1}\right)$ dengan variabel kualitas audit (Y). Semakin tinggi profesionalisme yang dimiliki auditor, maka kualitas audit yang dihasilkannya semakin meningkat.

3. Koefisien regresi pengalaman $\left(b_{2}\right)$ adalah 0,721dan bertanda positif. Hal ini berarti, nilai variabel $Y$ akan mengalami kenaikan sebesar 0,721 jika nilai variabel $\mathrm{X}_{2}$ mengalami kenaikan satu satuan dan variabel independen lainnya bernilai tetap. Koefisien bertanda positif menunjukkan adanya hubungan yangsearah antara variabel pengalaman $\left(X_{2}\right)$ dengan variabel kualitas audit (Y). Semakin tinggi pengalamanyang dimiliki oleh auditor maka semakin kualitas audit yang dihasilkannya semakin baik.

4. Koefisien regresi pengetahuan auditor $\left(b_{3}\right)$ adalah0,583 dan bertanda positif. Hal ini berarti, nilai variabel $\mathrm{Y}$ akan mengalami kenaikan sebesar 0,583 jika nilai variabel $\mathrm{X}_{3}$ mengalami kenaikan satu satuan dan variabel independen lainnya bernilai tetap. Koefisien bertanda positif menunjukkan adanya hubungan yang searah antara Pengetahuan $\left(\mathrm{X}_{3}\right)$ dengan variabel kualitas audit (Y). Semakin tinggi pengetahuan yang dimiliki oleh auditor, maka kualitas audit yang dihasilkankan semakin baik. 
$\underline{\text { Uji R }}{ }^{2}$ (Koefisien Determinasi)

Uji koefisien determinasi bertujuan untuk mengetahui seberapa besar kemampuan variabel dependen dapat dijelaskan oleh variabel independen.

\begin{tabular}{|l|r|r|r|r|}
\hline $\begin{array}{l}\text { Mod } \\
\text { el }\end{array}$ & R & $\begin{array}{c}\text { R } \\
\text { Squa } \\
\text { re }\end{array}$ & $\begin{array}{c}\text { Adjust } \\
\text { ed R } \\
\text { Square }\end{array}$ & $\begin{array}{c}\text { Std. Error } \\
\text { of the } \\
\text { Estimate }\end{array}$ \\
\hline 1 & $\begin{array}{r}.71 \\
5^{\mathrm{a}}\end{array}$ & .511 & .462 & 2.55401 \\
\hline
\end{tabular}

Rerdapat angka $\mathrm{R}$ sebesar 0,715 yang menunjukkan bahwa hubungan antara Kualitas Audit dengan ketiga variabel independen nya kuat. Sedangkan nilai $\mathrm{R}$ square sebesar $\quad 0,511$ atau $\quad 51 \%$ ini menunjukkan bahwa variabel kualitas audit dapat dijelaskan oleh variabel profesionalisme, pengalaman, dan pengetahuan auditorsebesar $51 \%$ sedangkan sisanya $49 \%$ dapat dijelaskan dengan variabel lain yang tidak terdapat pada penelitian ini.

\section{$\underline{\text { Hasil Uji Parsial }}$}

\section{Coefficients $^{\mathrm{a}}$}

\begin{tabular}{|r|r|r|}
\hline \multicolumn{1}{|c|}{ Model } & \multicolumn{1}{c|}{$\mathrm{t}$} & \multicolumn{1}{c|}{ Sig. } \\
\hline $\begin{array}{l}\text { (Constant) } \\
\begin{array}{l}\text { Profesiona } \\
\text { lisme }\end{array}\end{array}$ & 2.183 & .049 \\
$1 \begin{array}{l}\text { Pengalam } \\
\text { an }\end{array}$ & 2.499 & .018 \\
$\begin{array}{l}\text { Pengetahu } \\
\text { an }\end{array}$ & 2.289 & .029 \\
\hline
\end{tabular}

Melalui statistik uji-t yang terdiri dari Profesionalisme $\left(\mathrm{X}_{1}\right)$, Pengalaman $\left(\mathrm{X}_{2}\right)$, danPengetahuan Auditor $\left(\mathrm{X}_{3}\right)$ dapat diketahui secara parsial pengaruhnya terhadap Kualitas Audit (Y).

\section{Pengujian Hipotesis Pertama $\left(\mathrm{H}_{1}\right)$}

Tabel pengujian hipotesis di atas menunjukkan bahwa variabel profesionalisme memiliki tingkat signifikan sebesar 0,037 yaitu lebih kecil dari 0,05. Hal ini berarti $\mathrm{H}_{1}$ diterima sehingga dapat dikatakan bahwa profesionalisme berpengaruh signifikan terhadap kualitas audit. Nilai $t$ yang bernilai 2,183 menunjukkan pengaruh yang diberikan bersifat positif terhadap variabel dependen.

\section{Pengujian Hipotesis Kedua $\left(\mathrm{H}_{2}\right)$}

Tabel pengujian hipotesis di atas menunjukkan bahwa variabel pengalamanmemiliki tingkat signifikan sebesar 0,018 yaitu lebih kecil dari 0,05 . Hal ini berarti $\mathrm{H}_{2}$ diterima sehingga dapat dikatakan bahwa pengalaman berpengaruh signifikan terhadap kualitas audit. Nilai $t$ yang bernilai 2,499menunjukkan pengaruh yang diberikan bersifat positif terhadap variabel dependen

\section{$\underline{\text { Pengujian Hipotesis Ketiga }\left(\mathrm{H}_{3}\right)}$}

Tabel pengujian hipotesis di atas menunjukkan bahwa variabel pengetahuan auditormemiliki tingkat signifikan sebesar 0,029 yaitu lebih kecil dari 0,05. Hal ini berarti $\mathrm{H}_{3}$ diterima sehingga dapat dikatakan bahwa kompetensi berpengaruh 
signifikan terhadap kualitas audit.Nilai $t$ yang bernilai 2,289 menunjukkan pengaruh yang diberikan bersifat positif terhadap variabel dependen.

\section{$\underline{\text { Pembahasan }}$}

\section{Pengaruh Profesionalisme Terhadap Kualitas Audit \\ Profesionalisme berpengaruh} positif dan signifikan terhadap kualitas audit. Profesionalisme Auditor Internal dapat diartikan sebagai sikap dan perilaku auditor dalam menjalankan profesinya dengan kesungguhan dan tanggung jawab agar mencapai kinerja tugas sebagaimana yang diatur oleh organisasi profesi, meliputi pengabdian pada profesi, kewajiban sosial, kemandirian, keyakinan profesi dan hubungan dengan rekan seprofesiJadi, semakin profesional seorang auditor dalm mengerjakan tugasnya maka kualitas audit yang dihasilkan akan semakin meningkat.

2. Pengaruh Pengalaman Auditor Terhadap Kualitas Audit

Pengalaman auditor berpengaruh positif dan signifikan terhadap kualitas audit. Pengalaman adalah proses pembelajaran diri yang diperoleh dari pendiikan formal maupun non formal. Pengalaman kerja merupakan penguasaan dan pemahaman seseorang atas pekerjaannya. Pengalaman dan pengetahuan merupakan faktor penting untuk meningkatkan keahlian (Purnamasari, 2005). Pengalaman seorang auditor dapat diukur dari lamanya seorang auditor bekerja, banyaknya kasus yang dikerjakan, dan seringnya pelatihan yang diikuti.

Jadi, dapat disimpulkan bahwa semakin berpengalam seorang auditor dalam mengerjakan auditnya, maka kualitas audit yang dihasilkan akan semakin baik.

3. Pengaruh Pengetahuan Terhadap Kualitas Audit

Pengetahuan auditor berpengaruh positif dan signifikanterhadap kualitas audit. Pengetahuan disini juga bisa diperoleh dari frekuensi seorang akuntan publik dalam melakukan suatu pekerjaan dalam proses pengauditan suatu laporan keuangan. Seseorang yang melaksanakan pekerjaan sesuai dengan pengetahuan yang dimiliki akan memberikan hasil yang lebih baik dari pada mereka yang tidak memiliki pengetahuan yang cukup memadai akan tugasnya. Pengetahan auditor adalah hal yang sangat penting dalam meningkatkan kualitas audit. Pengetahuan auditor yang tinggi dan luas juga dapat mempengaruhi kualitas audit. Pengetahuan auditor biasanya dapat diukur dengan tingkat pengalaman kerja sebagai seorang auditor. Semakin lama auditor memperoleh pengalaman kerja maka akan dapat dikatakan semakin tinggi juga tingkat pengetahuan yang mereka miliki atau peroleh (Salsabila dan Prayudiawan,2011:158). Jadi semakin berpengetahuan seorang auditor maka kualitas audit yang dihasilkan akan semakin meningkat. 


\section{KeSIMPULAN}

Berdasarkan data yang telah dikumpul dan pengujian hipotesis dengan analisis regresi linear berganda telah dilakukan, maka kesimpulan dari penelitian ini adalah sebagaiberikut :

1. Profesionalisme berpengaruh positif dan signifikan terhadap kualitas audit.

2. Pegalaman berpengaruh positifdan signifikan terhadap kualitas audit.

3. Pengetahuan Auditorberpengaruh positif dan signifikan terhadap kualitas audit.

\section{SARAN}

Saran-saran yang dapat diberikan untuk penelitian selanjutnya adalah sebagaiberikut :

1. Masih dibutuh sampel yang lebih banyak sebab sampel yang ada pada penelitian ini terbatas pada auditor yang bekerja di Kantor Akuntan Publik Di Makassar. Disarankan Penelitian selanjutnya dapat menambah serta memperluas wilayah dan jumlah sampel.

2. Penelitian selanjutnya sebaiknya menambah jumlah variable baru selain dalam penelitian ini agar lebih mengetahui faktor-faktor apa saja yang dapat mempengaruhi kualitas audit. Karena masih terdapat variabel lain yang mempengaruhi kualitas audit selain variable penelitian ini, seperti pengetahuan akuntansi, bonus, pengalaman, prilaku disfungsional dan moderasi pemahaman terhadap system informasi

\section{DAFTAR PUSTAKA}

Anita Kusuma Dewi. (2010). Pengaruh Profesionalisme Auditor terhadap Pertimbangan Tingkat Materialitas dalam Proses Pengauditan Laporan Keuangan (Studi Empiris pada Auditor di KAP Kota Yogyakarta). Skripsi. Yogyakarta: Univesitas Negeri Yogyakarta.

Agoes, Sukrisno. 2007. Auditing Oleh KAP. Lembaga Penerbit Fakultas Ekonomi Universitas Indonesia, Jakarta.

Al Haryono Jusup. 2001. Auditing. Yogyakarta: Bagian Penerbit Sekolah Tinggi Ilmu Ekonomi YKPN.

Arens, Alvin A., Mark S. Beasley \& Randal J. Endar. 2011. Auditing and Assurance Services. Pearson Education Limitid, England

Asih, Dwi Ananing Tyas. 2006. Pengaruh Pengalaman Terhadap Peningkatan Keahlian Auditor dalam Bidang Auditing. Skripsi tidak dipublikasikan.. Yogyakarta: Fakultas Ekonomi Universitas Islam Indonesia.

Budiman. M. Arif. 2010. Pengaruh Audit Jugement, Independensi, dan Komitmen Profesional Auditor Terhadap Kualitas Audit. Skripsi. UIN Syarif Hidayatullah, Jakarta.

Cahya Baharuddin . 2014. Pengaruh Time Pressure, Fee Audit, dan Motivasi Auditor terhadap Kualitas Audit (Study Pada BPKP Perwakilan Provinsi 
Sulawesi Selatan), Skripsi, Universitas Muslim Indonesia.

Christiawan, Yulius Jogi. 2003. Kompetensi dan Independensi Akuntan Publik: Refleksi Hasil Penelitian Empiris. Akuntansi dan Keuangan Vol.4 No. 2 (Nov) Hal. 79-92

Irwan Hasan dan Khairani Siti, 2013. Pengaruh Sistem Administrasi Perpajakan Modern Terhadap Kepatuhan Wajib Pajak Pada Kantor Pelayanan Pajak Madya Palembang. Jurnal

Kalbers Lawrence P. dan Timothi J. Fogarty. 1995. Profesionalism and its Consequences: A Study of Internal Auditors. Auditing a Journal of Practice and Theory. Vol.14. No.1 Pp. 6486.

Lestari Ayu Made Ni dan Utama Karya Made I. (2012). Pengaruh Profesionalisme, Pengetahuan Mendeteksi Kekeliruan, Pengalaman, Etika Profesi Pada Pertimbangan Tingkat Materialitas.

Purnamasari. 2005. Pengaruh Pengalaman Kerja Terhadap Hubungan Partisipasi dengan Efektivitas Sistem Informasi. Jurnal Riset Akuntansi Keuangan. 1 (3)

Ramdanialsyah. 2010. Pengaruh Tekanan Klien, Pengalaman Auditor, dan Profesionalisme Auditor Terhadap Kualitas Audit. Skripsi, Universitas Islam Negeri.

Achmad Badjuri. Faktor Faktor yang berpengaruh terhadap Kualitas Audit Auditor Independen Pada Kantor Akuntan Publik (KAP) Di Jawa Tengah.
Dinamika Keuangan

Perbankan, November 2011

Vol3, No.2 Hal; 183 197, ISSN:1979-4878

Andi Supangat, 2007, Statistik: Dalam Kajian Deskriftif, Inferensi

Dannonparamentrik, Jakarta: Kencana

Anton Eka Saputra.2012. Pengaruh Kompetensi Dan Independensi Terhadap Kualitas Audit Dengan Etika Auditor Sebagai Varabel Moderasi (Studi Empiris Pada auditor Dikantor Akuntan Publik Se-Jawa Tengah Dan D.I Yogyakarta) . Juraksi . Vol.1 No.2 Februari ISSN; 2301-9328

De Angelo, L.E 1981, Auditor Size And Auditor Quality, Journal Of Accounting And Economics

Feni, Yohanes , Pengaruh Akuntabilitas Dan Kompetensi Auditor Terhadap Kualitas Audit (Studi Empiris Pada Akuntan Publik Semarang). Juraksi. Vol.1 No.1 Januari 2012. ISSN: 2301-9328

Lilis Ardini. Pengaruh Kompetensi, Dan Independensi, Akuntabilitas Dan Motivasi Terhadap Kualitas Audit. Majalah Ekonomi. Tahun XX, No.3 Desember 2010 Hal 329349

Ricca Rosalina Sari,2012. Pengaruh Kompetensi Dan Independensi Auditor Terhadap Kualitas Audit (Studi Empiris Pada Kntor Akuntan Publik Di Kota Semarang) Juraksi Vol.1 No.2 Februari. ISSN: 2301-9328

Sekar Mayangsari Puspawadanarum, 2013. Auditing Pendekatan 
Sektor Publik Dan Privat.

Jakarta : Media Bangsa

Sukrisni Agoes, 2012. Auditing

Petunjuk Praktis Pemeriksaan

Akuntan Oleh Akuntan Publik.

Jakarta : Salemba Empat.

Sugiyono. 2012. Metode Penelitian

Pendidikan Pendekatan

Kuantitatif, Kualitatif,

Bandung : Alfabeta 